\title{
Penyuluhan Perawatan dan Perbaikan Sepeda Motor Injeksi di Desa Pundensari Kecamatan Purwodadi
}

\author{
Widiyatmoko, Mike Elly Anitasari \\ Program Studi Pendidikan Teknik Otomotif, FKIP, Universitas Muhammadiyah Purworejo \\ Email: widiyatmoko@umpwr.ac.id
}

\begin{abstract}
Abstrak - Tujuan dari kegiatan pengabdian masyarakat ini adalah Tujuan dari kegiatan pengabdian masyarakat ini adalah memberikan pengetahuan tentang perawatan dan dan perbaikan sepeda motor injeksi, dan mengembangkan keterampilan dan kreativitas remajal pemuda (karang taruna) dalam bentuk kegiatankegiatan edukatif, kreatif dan inovatif dalam dunia otomotif. Sasaran Pengabdian Kepada Masyarakat ini adalah Sasaran Pengabdian Kepada Masyarakat ini adalah para remaja, pemuda karang taruna, dan aparatur desa Pundensari Kecamatan Purwodadi dengan jumlah peserta sebanyak 19 orang. Permasalahan diselesaikan dalam tiga (3) tahapan kegiatan, yakni persiapan, pelaksanaan, dan evaluasi. Pada tahap persiapan yang dilakukan adalah menganalisa masalah dan kebutuhan. Tahap kedua yaitu pelaksanaan terbagi menjadi beberapa sesi yaitu pembukaan, penyampaian materi toeri singkat, dan dilanjutkan dengan dialog interaktif atau diskusi. Metode pelaksanaan kegiatan ini adalah dengan penyampaian atau penyuluhan materi tentang perawatan dan perbaikan sepeda motor injeksi dilanjutkan diskusi, dialog interaktif tentang permasalahan atau troubel-troubel di sepeda motor injeksi. Tahap ketiga yakni evaluasi dengan audiensi dengan pendekatan masalah. Hasil dari pelaksanaan pengabdian kepada masyarakat dapat diuraikan dalam indikator sebagai berikut: 1) Pelaksanaan kegiatan pengabdian berlangsung dengan kondusif, baik, dan lancar sesuai dengan perencanaan, 2) Berdasarkan hasil umpan balik dari para peserta, didapatkan penilaian bahwa kegiatan ini sangat sangat dibutuhkan oleh para seserta mengingat jauhnya akses desa pundensari dengan bengkel resmi sepeda motor Honda atau Yamaha, 3) Para peserta mendapatkan wawasan dan pengetahuan baru dan lebih luas tentang cara perawatan dan perbaikan sepeda motor Injeksi.
\end{abstract}

Kata kunci: sepeda motor, injeksi, perawatan

\section{COACHING HOW TO MAINTAIN AND REPAIR ON INJECTION MOTORCYCLE PUNDENSARI, PURWODADI}

\begin{abstract}
The purpose of activity is to provide community knowledge about the maintenance and repair of injection motorcycle, and developing the skills and creativity. these activities are related to automotive. The object is automotive community service; teenager, youth in Pundensari with 19 participants. The problem is to solve three stages; preparation, implementation, and evaluation. In preparation phase, the problem is carried out by analyzing the problem and need. The second stage, implementation, it is divided into several sessions; opening, coaching of brief theory, and interactive discussion. The method is the coaching material about how to maintain and repair injection motorcycles by discussions, interactive discussion about problems in injection motorcycle. The third is evaluation by listening the audience. The results can be described in the following indicators: 1) The implementation is conducive, good, and smooth, 2) Based on the result of feedback from the participants, it is found that this activity is needed by the participants as well. It is important and economic because of the long distance from Pundensari the official center of service and maintenance both Honda and Yamaha, 3) Participants got new knowledge about how to care and repair Injection motorcycle.
\end{abstract}

Keywords: injection, motorcycle, care 


\section{PENDAHULUAN}

Berkaitan dengan keterserapan alumni Sekolah Menengah Kejuruan dan atau Sekolah Menengah Atas (SMK/ SLTA) di dunia kerja idealnya adalah berkisar antara $80 \%$ sampai $85 \%$, tetapi kenyataannya pada tahun 2007 daya serap industri hanya 61\% (Samsudi, 2008: 1). Menurut Kohort siswa SMK/SLTA 2010-2014 lulusan yang akan terserap di dunia kerja pada tahun kelulusan yang sama sebesar 70\% baru akan tercapai pada tahun 2014 (Sutrisno, 2009). Kondisi ini menunjukkan bahwa lulusan yang belum terserap di industri atau belum bekerja masih tergolong tinggi.

Menghadapi kondisi di atas, organisasi yang ada di masyarakat seperti karang taruna setidaknya sangat memungkinkan menangkap hal tersebut yang selanjutnya menindaklanjuti dengan mengadakan program-program yang bermanfaat bagi anggota karang taruna, yang dapat dijadikan sebagai tambahan ketrampilan atau bahkan bekal untuk mendapatkan pekerjaan. Dengan banyaknya anggota masyarakat khususnya remaja yang tergabung dalam karang taruna yang masih masa tunggu untuk mendapatkan pekerjaan, atau bahkan yang belum dapat bekerja karena tidak memiliki ketrampilan tertentu, diperlukanlah sebuah kegiatan yang dapat menarik minat pada pemuda karang taruna.

Pelatihan mekanik yang berupa keterampilan perawatan sepeda motor khususnya sepeda motor dengan teknologi terbaru ini merupakan suatu alternatif untuk menjembatani kondisi yang ada agar dapat mencapai harapan yang diinginkan. Melalui kegiatan ini dimungkinkan kegiatan remaja/ pemuda yang tergabung dalam karang taruna akan dapat terkelola baik sehingga kiprahnya akan semakin baik pula. Dengan demikian, budaya untuk berorganisasi dan memanfaatkan waktu luang akan jauh bermanfaat.

\section{METODE}

Metode Kegiatan pengabdian kepada masyarakat dalam bentuk penyuluhan perawatan dan perbaikan ringan sepeda motor sistem injeksi. Penyuluhan disampaikan dalam bentuk ceramah dan dialog interaktif atau diskusi.

\section{Kegiatan dan Pelaksanaan}

Kegiatan ini merupakan rangkaian kegiatan pengabdian kepada masyarakat yang didanai oleh LPPM Universitas Muhammadiyah Purworejo.

\section{Waktu dan Tempat Pengabdian}

Waktu pelaksanaan pengabdian kepada masyarakat dilaksanakan pada tanggal 20 Februari 2019. Pelaksanan pengabdian dilaksanakan pada pukul 08.30 sampai dengan pukul 11.30 WIB. Bertempat di Aula atau balai desa, Desa Pundensari Kecamatan Purwodadi.

\section{Mitra/Subjek Pengabdian}

Mitra pelaksanaan pengabdian adalah muda mudi, remaja, bapak-bapak yang tergabung dalam karang taruna desa Pundensari dan seluruh aparatur desa Pundensari Kecamatan Purwodadi yang diikuti oleh 19 orang peserta.

\section{Prosedur}


Secara umum langkah-langkah kegiatan Pengabdian Kepada Masyarakat inibisa dibagi dalam tiga tahap yakni persiapan, pelaksanaan, dan evaluasi.

Pada tahap persiapan Pengabdian Kepada Masyarakat dilakukan dengan menganalisa masalah dan kebutuhan peserta penyuluhan, mencari data dan informasi, mengidentifikasi masalah dan mencari upaya untuk membantu mengatasi masalah yang muncul.

Tahap kedua yaitu pelaksanaan pengabdian yang terbagi menjadi beberapa sesi yaitu pembukaan, penyampaian materi teori singkat, dilanjutkan dengan diskusi berbagai permasahan dan solusi yang terkait dengan perawatan dan perbaikan sepeda motor injeksi.

Pengabdian Kepada Masyarakat ini ditutup dengan evaluasi hasil akhir dengan tanya jawab dan diskusi untuk mengetahui daya serap yang dapat ditangkap oleh peserta sebagai evaluasi dan rekomendasi kegiatan selanjutnya. Selanjutnya untuk mengetahui tingkat partisipasi peserta akan kegiatan tersebut, setiap peserta mengisi angket sebagai tanggapan peserta akan kegiatan yang telah dilaksanakan.

\section{Data, Intrumen, dan Teknik Pengumpulan Data}

Data pada kegiatan pengabdian ini diperoleh berdasarkan hasil pengamatan, tanya jawab yang dilakukan pemateri dengan peserta. Adapun data efektifitas pelaksanaan pengabdian dikumpulkan melalui angket yang disampaikan kepada peserta untuk memberikan tanggapan akan keterlakasanaan kegiatan pengabdian

\section{Teknik Analisis Data}

Data yang telah diperoleh dari hasil pengamatan, tanya jawab, dan tanggapan dari seluruh peserta yang mengikuti kegiatan pengabdian, selanjutnya data tersebut kemudian dilakukan analisis dengan analisis deskriptif.

\section{HASIL DAN PEMBAHASAN}

Berdasarkan rekap tanggapan dari peserta penyuluhan perawatan dan perbaikan sepeda motor injeksi didapatkan hasil sebagai berikut:

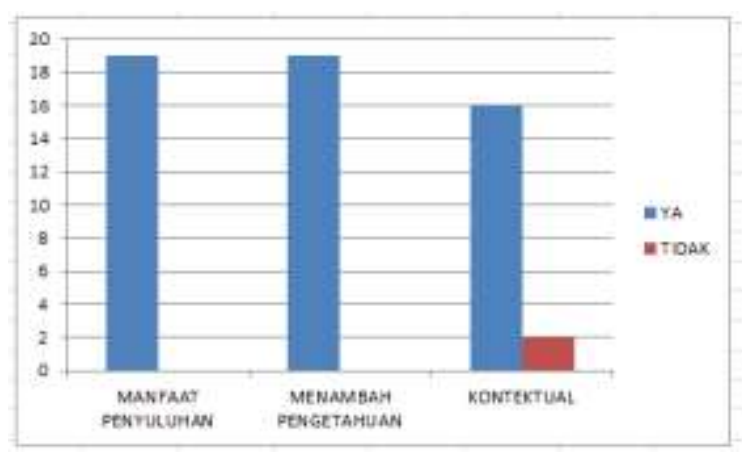

Gambar 1. Pernyataan peserta penyuluhan

Dari sejumlah peserta atau responden sejumlah 19 orang, yang memberikan tanggapan bahwa penyuluhan bermanfaat bagi responden adala sejumlah 19 orang. Artinya semua peserta yang mengikuti penuluhan menyatakan bahwa kegiatan penyuluhan memberikan 
manfaat. Demikian juga pernyataan yang menyatakan bahwa materi penyuluhan menambah pengetahuan dan wawasan juga disampaikan oleh semua peserta penyuluhan.

Adapun peserta yang menyatakan bahwa materi penyuluhan kontektual disampaikan oleh peserta sejumlah 16 orang. Dan hanya 3 orang saja yang menyatakan penyuluhan tidak kontektual.

Berdasarkan dari sajian gambar tersebut dapat dijelaskan bahwa program pengabdian yang berupa penyuluhan perawatan dan perbaikan sepeda motor injeksi benar-benar bermanfaat dan menambah pengetahuan dan wawasan tentang perawatan dan perbaikan sepeda motor injeksi. Karena sebagaimana yang diungkapkan oleh peserta penyuluhan bahwa secara geografis/ letak desa pundensari memiliki akses yang jauh dengan bengkel resmi sepeda motor.

Selanjutnya data penelitian atau tanggapan responden yang menyatakan bahwa sebagian besar (16 orang) menyatakan bahwa materi penyuluhan kontetual hal ini sangat berkaitan dengan banyaknya peserta yang sebagian besar sudah menggunakan sepeda motor dengan sistem injeksi.

Selanjutnya berkaitan dengan tanggapan mengenai daya serap dari peserta setelah selesai penyuluhan adalah sebagai berikut:

Tabel 1. Daya serap materi

\begin{tabular}{|c|c|}
\hline Daya serap (\%) & Jumlah (orang) \\
\hline 50 & 1 \\
\hline 60 & 1 \\
\hline 70 & 3 \\
\hline 80 & 5 \\
\hline 90 & 5 \\
\hline 95 & 4 \\
\hline
\end{tabular}

Berdasarkan tabel diatas dapat dinyatakan bahwa responden atau peserta penyuluhan yang memberikan tanggapan tentang daya serap, sejumlah 14 orang menyatakan daya serap diatas $70 \%$. hal tersebut dapat dimungkinkan dikarenakan peserta penyuluhan sebagian besar adalah laki laki yang dari sebagian besar mereka ada yang berprofesi sebagai pelaku bengkel. Dan sebagian yang lain menurut data yang didapati selama audiensi, mereka memiliki kesenangan atau hobi melakukan perawatan mandiri atas kendaraan mereka ketika mendapati kerusakan yang masih bisa mereka atasi, dan Mengingat kondisi desa yang memilki jarak dan akses yang jauh untuk membawa sepeda motor mereka ke bengkel sepeda motor.

\section{SIMPULAN DAN SARAN}

\section{Simpulan}

Berdasarkan tanggapan yang diberikan oleh peserta, dapat ditarik kesimpulan sebagai berikut: 1) Pelaksanaan kegiatan pengabdian berlangsung dengan baik sesuai dengan perencanaan, 2) Berdasarkan hasil umpan balik dari para peserta, didapatkan penilaian bahwa kegiatan ini sangat dibutuhkan oleh para seserta mengingat jauhnya akses desa pundensari dengan bengkel resmi sepeda motor, 3) Para peserta mendapatkan 
tambahan wawasan dan pengetahuan baru dan lebih luas tentang cara perawatan dan perbaikan sepeda motor Injeksi.

\section{Saran}

Dengan tersampaikannya seluruh materi dan informasi dalam penyuluhan, disarankan pihak kampus UMP bisa melaksanakan tindak lanjut dari kegiatan pengabdian ini. Pengetahuan dan informasi yang diterima oleh peserta diharapkan dapat diaplikasikan, diterapkan dan disebarluaskan kepada yang lain untuk kemanfaatan yang lebih luas.

\section{DAFTAR PUSTAKA}

AHM. Buku Pedoman reparasi Honda PGM-FI Supra X 125.Jakarta: PT. Astra Honda Motor.

M. Suratman. 2003. Servis dan Teknik Reparasi Sepeda Motor. Bandung: CV. Pustaka Grafika Yamaha Technical Academy. YAMAHA MOTOR CO.LTD 